\title{
Clinical Statistics of Inpatients for a Six-year Period
}

By

Akira Kitamura, Jun Kanbara, Nobuhiko Kohno,

Ryusuke Nagai and Shunsuke Nakatomi

Second Department of Oral Surgery (Director: Prof. Shigeru Ikejiri)

Kyushu Dental College, Kokura, Kitakyushu, Japan.

\section{I) Introduction}

During the six-year period, 1966-1971, a total of 1,306 inpatients were treated in the 2nd Department of Oral Surgery, Kyushu Dental College, and investigated from a clinical stand point. They were divided collectively into malformation, inflammation, traumatic disease, benign tumor, malignant tumor and others. A few of these were investigated in detail.

The outline of these figures is discussed and reported in this paper.

\section{II ) Materials}

The materials used in this survey are the inpatient records of the 2nd Department of Oral Surgery, Kyushu Dental College, during the aforementioned six-year period, with 1,306 cases referred to the department. Patients admitted more than one time with the same disease were considered as separated cases each time.

\section{III) Results}

1. Frequency of Each Group and Yearly Transition

In all of the cases classified by groups and years, the malformation group, such as cleft lip and/or palate, was the most frequent (567 cases; 43.4\%). The remaining groups, shown in descending order of incidence, were: inflammation (237 cases; 18.1 $\%)$, cystic disease (130 cases; $10.0 \%)$, traumatic disease (110 cases; $8.4 \%)$, malignant tumor (99 cases; $7.6 \%$ ), benign tumor (93 cases; $7.1 \%$ ), and others (70 cases; 5.4 $\%)$. Generally, these groups remained in the same order, but recently malignant tumor cases reported seem to be increasing in number.

Table 1. YEARLY TOTAL OF EACH GROUP

\begin{tabular}{l|r|r|r|r|r|r|r}
\hline & year 1966 & '67 & '68 & '69 & '70 & '71 & Total $(\%)$ \\
\hline Malformation & 108 & 79 & 80 & 95 & 106 & 99 & $567(43.4)$ \\
Inflammation & 37 & 37 & 46 & 44 & 41 & 32 & $237(18.1)$ \\
Traumatic disease & 28 & 17 & 22 & 18 & 12 & 13 & $110(8.4)$ \\
Cystic disease & 21 & 13 & 18 & 27 & 27 & 24 & $130(10.0)$ \\
Benign tumor & 15 & 15 & 18 & 15 & 14 & 16 & $93(7.1)$ \\
Malignant tumor & 15 & 16 & 18 & 11 & 16 & 23 & $99(7.6)$ \\
Others & 7 & 12 & 9 & 19 & 13 & 10 & $70(5.4)$ \\
\hline \multicolumn{1}{c}{ Total } & 231 & 189 & 211 & 229 & 229 & 217 & $1306(100.0)$ \\
\hline
\end{tabular}




\section{Monthly Change (Table 2)}

The total number of cases reported by month shows a decrease in December and an increase in January. The average number of cases per month was 109 .

Table 2. MONTHLY DISTRIBUTION OF INPATIENTS

\begin{tabular}{l|r|r|r|r|r|r|r|r|r|r|r|r|r} 
& month 1 & \multicolumn{1}{|c}{2} & \multicolumn{1}{|c|}{3} & 4 & $\mathbf{5}$ & 6 & 7 & 8 & 9 & 10 & 11 & 12 & Total \\
\hline Malformation & 71 & 56 & 45 & 40 & 48 & 44 & 62 & 56 & 43 & 51 & 38 & 13 & 567 \\
Inflammation & 27 & 27 & 18 & 16 & 22 & 21 & 13 & 10 & 18 & 23 & 24 & 18 & 237 \\
Traumatic disease & 10 & 9 & 5 & 13 & 12 & 8 & 13 & 3 & 12 & 6 & 9 & 10 & 110 \\
Cystic disease & 11 & 9 & 7 & 10 & 18 & 14 & 9 & 8 & 11 & 10 & 10 & 13 & 130 \\
Benign tumor & 10 & 5 & 10 & 7 & 9 & 9 & 10 & 12 & 10 & 5 & 4 & 2 & 93 \\
Malignant tumor & 9 & 14 & 4 & 3 & 7 & 11 & 6 & 9 & 12 & 11 & 6 & 7 & 99 \\
Others & 8 & 7 & 7 & 5 & 2 & 9 & 5 & 5 & 5 & 5 & 8 & 4 & 70 \\
\hline Total & 146 & 127 & 96 & 94 & 118 & 116 & 118 & 103 & 111 & 111 & 99 & 67 & 1306 \\
\hline
\end{tabular}

3. Sex and Age Incidence (Table 3)

The findings of this item are described in each section.

Table 3. CLASSIFICATION OF SEX AND AGE IN EACH GROUP

\begin{tabular}{l|r|r|r|r|r|r|r|r|r|r|r}
\hline & SEX M & F & YEARS - & $10-19$ & $20-29$ & $30-39$ & $40-49$ & $50-5960-69$ & $70-$ & Total \\
\hline Malformation & 316 & 251 & 391 & 115 & 49 & 7 & 5 & 0 & 0 & 0 & 567 \\
Inflammation & 120 & 117 & 55 & 34 & 41 & 38 & 35 & 18 & 9 & 7 & 237 \\
Traumatic disease & 89 & 21 & 13 & 26 & 33 & 18 & 9 & 5 & 5 & 1 & 110 \\
Cystic disease & 66 & 64 & 7 & 10 & 23 & 28 & 24 & 25 & 10 & 3 & 130 \\
Benign tumor & 42 & 51 & 7 & 17 & 15 & 15 & 6 & 13 & 11 & 9 & 93 \\
Malignant tumor & 67 & 32 & 1 & 0 & 3 & 5 & 23 & 19 & 25 & 23 & 99 \\
Others & 32 & 38 & 3 & 10 & 14 & 10 & 11 & 5 & 13 & 4 & 70 \\
\hline Total & 732 & 574 & 477 & 212 & 178 & 121 & 113 & 85 & 73 & 47 & 1306 \\
\hline
\end{tabular}

4. Period of Hospitalization and Bed-utilization Rates (Table 4)

Table 4. COMPARISON OF THE INPATIENT TOTAL, PERIOD OF HOSPITALIZATION AND THE BED-UTILIIZATION RATES

\begin{tabular}{l|c|c|c}
\hline & Inpatient (total) & Hospitalization (days) & Bed-utilization (\%) \\
\hline Malformation & 567 & 39.5 & 43.9 \\
Inflammation & 237 & 21.7 & 10.3 \\
Traumatic disease & 110 & 40.0 & 7.9 \\
Cystic disease & 130 & 31.2 & 8.0 \\
Benign tumor & 93 & 46.9 & 8.8 \\
Malignant tumor & 99 & 89.8 & 17.5 \\
Others & 70 & 38.9 & 3.6 \\
\hline Mean & 187 & 44.0 & \\
\hline
\end{tabular}


Malignant tumor cases required the longest period of hospitalization (89.8 days), while inflammation cases required the shortest period $(23.5 \%)$. Malformation cases had the highest rate of bed utilization $(43.7 \%)$ and traumatic disease cases were the lowest with $7.9 \%$. The percentage for malignant tumor cases was $17.5 \%$.

5. Malformation

There was a total of 567 cases of malformation. Cleft lip and/or palate comprised 560 cases and accounted for $98.8 \%$ of the total. The rest of the malformations were nasality (4 cases) and progenia (3 cases). Of the 560 cleft malformation cases, 344 had been operated on at our clinic or other medical centers. The remaining 216 cases were admitted for initial treatment. Of these 216 cases there were 88 cases (4 $0.7 \%)$ of cleft palate. 80 cases $(37.0 \%)$ of cleft lip and palate, and 48 cases $(22.3 \%)$ of cleft lip (Table 6). The cleft occurring on the left side accounted for 63 cases and were 1.7 times more frequent than the cleft on the right side with 37 cases. There were also 28 bilateral cases. The total number of incomplete and complete cleft was equal with 59 cases of each, but the remaining 10 cases could not be classified separately because of having both incomplete and complete clefts (Table 5). Comparison of malformation incidence by sex showed that there were 40 cases each for cleft lip and palate. In cleft lip and/or alveolus there were 34 cases for males and 14 cases for females, for a ratio of 2.43 to 1 . In cleft palate, however, there were 59 female cases and 29 male cases, for a ratio of 2 to 1 (Table 6).

Table 5. PREOPERATIVE LOCATION OF CLEFT

\begin{tabular}{|c|c|c|c|c|c|c|c|c|}
\hline & \multicolumn{2}{|c|}{ right } & \multicolumn{2}{|c|}{ left } & \multicolumn{3}{|c|}{ bilateral } & \multirow{2}{*}{ Total } \\
\hline & incomplete & complete & incom. & com. & incom. & com. & incom. + com. & \\
\hline \multirow{4}{*}{$\begin{array}{l}\text { Lip } \\
\text { Lip and alveolus } \\
\text { Lip, alveolus and palate } \\
\text { Lip and palate }\end{array}$} & 10 & 5 & 21 & 1 & 2 & & & 39 \\
\hline & 2 & & 5 & & & 1 & 1 & 9 \\
\hline & 5 & 15 & 5 & 26 & 4 & 11 & 9 & 75 \\
\hline & & & 5 & & & & & 5 \\
\hline \multirow{2}{*}{$\begin{array}{ll}\text { Palate } & \text { soft and hard } \\
\text { soft only }\end{array}$} & \multirow{2}{*}{\multicolumn{7}{|c|}{$\begin{array}{l}56 \\
32\end{array}$}} & 56 \\
\hline & & & & & & & & 32 \\
\hline
\end{tabular}

Table 6. CLASSIFICATION BY SEX OF CLEFT PATIENTS

\begin{tabular}{l|r|r|r}
\hline & male & female & Total $(\%)$ \\
\hline Cleft lip (prepalate) & 34 & 14 & $48(22.3)$ \\
Cleft lip and palate & 40 & 40 & $80(37.0)$ \\
Cleft palate & 29 & 59 & $88(40.7)$ \\
\hline Total & 103 & 113 & $216(100.0)$ \\
\hline
\end{tabular}


Primary cheiloplasty was performed in 116 cases $(90.6 \%)$ before the age of one year. Secondary cheiloplasty increased after the age of five years and was operated on in 130 cases $(95.5 \%)$ before the age of twenty. Primary palatoplasty accounted for 203 cases. Of these, 83 cases $(40.9 \%)$ were treated before age two, and 146 cases $(71.9 \%)$ before age five. Thirty-seven cases $(67.3 \%)$ of secondary palatoplasty were operated in from age one to age ten (Table 7).

Table 7. CLASSIFICATION OF CLEFT PATIENTS BY SEX AND OPERATED AGE

\begin{tabular}{l|c|c|c|c|c|c|c|c|c|c}
\hline & sex M & $\mathrm{F}$ & age -1 & $1-2$ & $2-5$ & $5-10$ & $10-15$ & $15-20$ & $20--$ & Total $(\%)$ \\
\hline $\begin{array}{c}\text { Cheiloplasty } \\
\text { (primary repair) }\end{array}$ & 73 & 55 & 116 & 4 & 3 & 3 & 1 & & 1 & $128(22.8)$ \\
$\begin{array}{c}\text { Cheiloplasty } \\
\text { (secondary repair) }\end{array}$ & 100 & 75 & 9 & 7 & 14 & 25 & 29 & 46 & 45 & $175(31.2)$ \\
$\begin{array}{c}\text { Palatoplasty } \\
\text { (cleft palate only) }\end{array}$ & 27 & 59 & 1 & 31 & 27 & 12 & 7 & 5 & 3 & $86(15.3)$ \\
$\begin{array}{c}\text { Palatoplasty } \\
\text { (after cheiloplasty) }\end{array}$ & 79 & 38 & & 51 & 36 & 11 & 7 & 5 & 7 & $117(20.9)$ \\
$\begin{array}{c}\text { Palatoplasty } \\
\text { (secondary repair) }\end{array}$ & 31 & 24 & & 4 & 18 & 15 & 4 & 8 & 6 & $55(9.8)$ \\
\hline Total & 310 & 251 & $126(22.4)$ & $97(17.3)$ & $98(17.4)$ & $66(11.8)$ & $48(8.6)$ & $64(11.4)$ & $62(11.1)$ & $561(100.0)$ \\
\hline
\end{tabular}

Ceiloplasty and palatoplasty were classified according to their operative technics and are shown in Table 8. Cheiloplasty and palatoplasty combined with the so-called push-back operation accounted for 252 cases $(44.9 \%)$ and 232 cases $(41.4 \%)$, respectively.

Table 8. DISTRIBUTION OF PROCEDURES FOR CLEFT

\begin{tabular}{l|c|c|c}
\hline & primary & secondary & Total (\%) \\
\hline Cheiloplasty & 128 & 124 & $252(44.9)$ \\
Pedicle graft of lip & & 26 & $26(4.6)$ \\
Rhinoplasty & & 25 & $25(4.5)$ \\
Palatoplasty & 198 & 34 & $232(41.4)$ \\
Alveoloplasty & & 14 & $14(2.5)$ \\
Pharyngeal flap transplantation & 5 & 7 & $12(2.1)$ \\
\hline Total & $331(59.0)$ & $230(41.0)$ & $561(100.0)$ \\
\hline
\end{tabular}

Pedicle graft of lip and rhinoplasty as a secondary cheiloplasty comprised 26 cases $(4.6 \%)$ and 25 cases $(4.5 \%)$, respectively. Alveoloplasty was performed on 14 cases (2 5\%) and pharyngeal flap transplantation was performed on 12 cases $(2.1 \%)$.

Patients who were treated for cheiloplasty and palatoplasty during one admission were listed as separate cases in each instance.

6. Inflammation (Table 9)

During the six-year test period, there were 237 cases of inflammation and its frequency decreased with age. Male and female cases (120 vs. 117) were almost the same 
in number. All cases were non-specific inflammation: odontogenic inflammation, 195 cases $(82.3 \%)$; maxillary sinusitis, 29 cases $(12.2 \%)$; and non-odontogenic inflammation, 13 cases $(5.5 \%)$.

Table 9. INFLAMMATION

\begin{tabular}{l|r|r|r|r|r|r|r}
\hline & year 1966 & '67 & '68 & '69 & '70 & '71 & Total $(\%)$ \\
\hline Periostitis & 7 & 16 & 20 & 18 & 20 & 9 & $90(38.0)$ \\
Maxillary sinusitis & 9 & 6 & 6 & 2 & 5 & 1 & $29(12.2)$ \\
Osteomyelitis & & 2 & & 1 & & 3 & $6(2.5)$ \\
Ostitis & 2 & & 3 & & & & $3(1.3)$ \\
Alveolar ostitis & 3 & 2 & 1 & 4 & 2 & 3 & $12(5.1)$ \\
Pericoronitis & 6 & 3 & 9 & 12 & 7 & 4 & $41(17.3)$ \\
Phlegmon & 6 & 4 & 4 & 4 & 4 & 7 & $29(12.2)$ \\
Lymhonoditis & 4 & & & & & & $4(1.7)$ \\
Abscess & & 2 & 1 & & & & $3(1.3)$ \\
External dental fistula & & 1 & & & & & $1(0.4)$ \\
Internal dental fistula & & 1 & 1 & 1 & 1 & & $4(1.7)$ \\
Kuettner's disease & & & & 1 & & 3 & $4(1.7)$ \\
Submaxillar glanditis & & & 1 & & 1 & 2 & $4(1.7)$ \\
Parotitis & & & & & 1 & & $1(0.4)$ \\
Acrodermatitis & 37 & 37 & 46 & 44 & 41 & 32 & $237(100.0)$ \\
\hline Total & & & & & & & \\
\hline
\end{tabular}

7. Traumatic Disease (Table 10)

Table 10. TRAUMATIC DISEASE

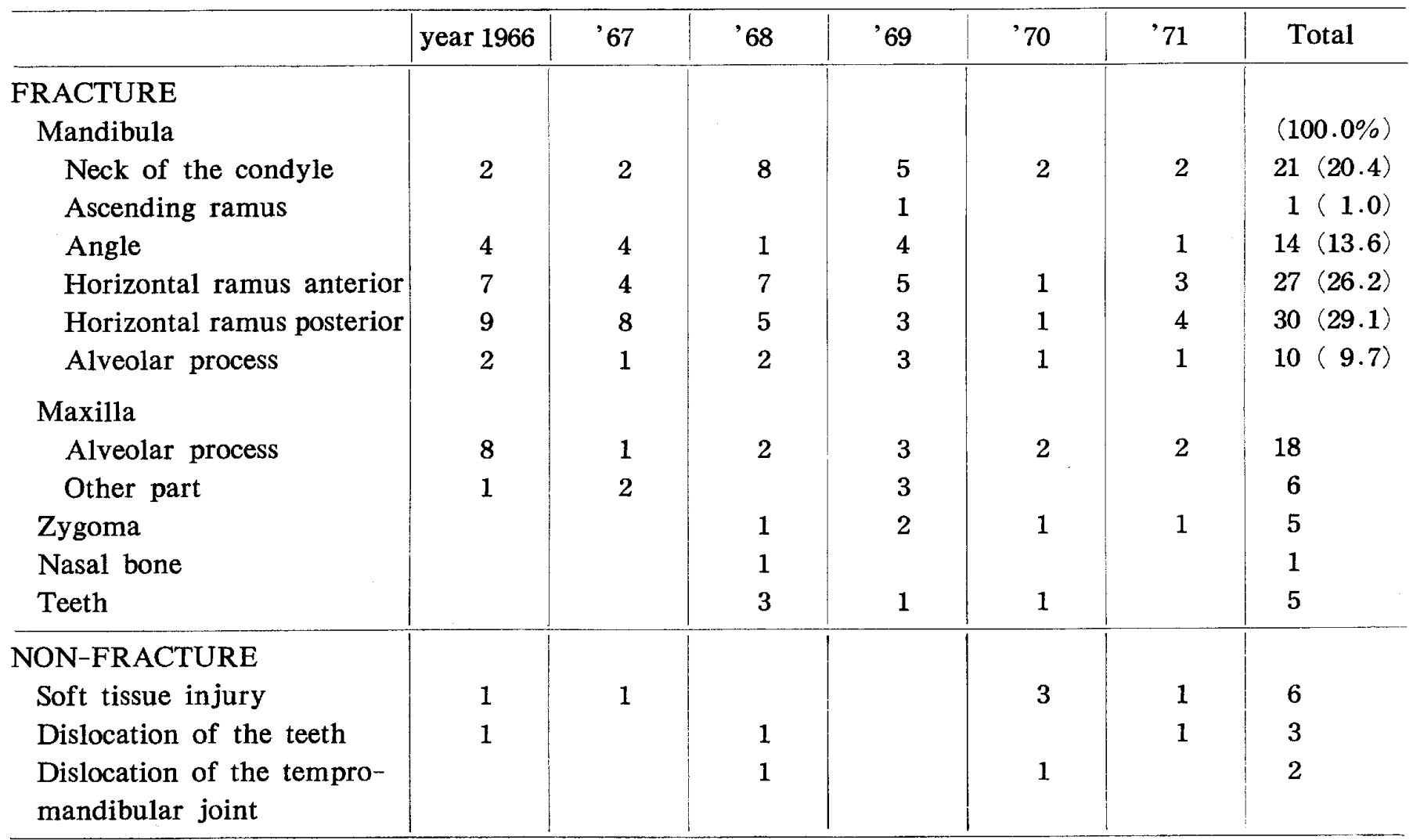


There were 110 cases of traumatic disease during the period studied. Incidence in males (89 cases) were four times as perdominant as in females (21 cases).

8. Cystic Disease (Table 11)

Table 11. CYSTIC DISEASE

\begin{tabular}{l|r|r|r|r|r|r|r}
\hline & year 1966 & '67 & '68 & '69 & '70 & '71 & Total (\%) \\
\hline Radicular cyst & 8 & 8 & 6 & 11 & 15 & 5 & $53(40.9)$ \\
Follicular cyst & 4 & 1 & 2 & 3 & 4 & 2 & $16(12.3)$ \\
Median maxillar cyst & & & & & 1 & & $1(0.8)$ \\
Globulomaxillary cyst & 1 & 1 & & & 2 & & $2(1.5)$ \\
Nasopalatine cyst & 6 & 1 & 7 & 10 & 3 & 9 & $36(27.7)$ \\
Postoperative buccal cyst & 1 & & & & & 1 & $2(1.5)$ \\
Mucous retention cyst & & 1 & 2 & & 1 & 2 & $6(4.6)$ \\
Ranula & 1 & 1 & & 2 & & 3 & $6(4.6)$ \\
Dermoid or epidermoid cyst & & & & & 1 & & $2(1.5)$ \\
Lateral cervical cyst & & & 1 & 1 & & 1 & $1(0.8)$ \\
Traumatic bone cyst & & & & & 1 & $3(2.3)$ \\
Others & 21 & 13 & 18 & 27 & 27 & 24 & $130(100.0)$ \\
\hline Total & & & & & &
\end{tabular}

A total of 130 cases of cystic disease was catergorized during this period, with an almost identical sex incidence frequency ( 66 male cases vs. 64 female cases).

There were 69 cases of odontogenic cysts, with 53 cases being radicular cysts. Of a total of 58 cases of non-odontogenic cysts, 36 cases were post operative buccal cysts. In 111 cases the cysts were found in hard tissue $(85.4 \%)$ and 16 cases were found in soft tissue $(12.3 \%)$.

One of the cysts in the cervical region had been operated on a total of eight times in another clinic ${ }^{11}$.

9. Benign Tumor (Table 12)

Table 12. BENIGN TUMOR

\begin{tabular}{|c|c|c|c|c|c|c|c|}
\hline & year 1966 & '67 & 68 & '69 & 70 & 71 & Total $(\%)$ \\
\hline Ameloblastoma & 4 & 11 & 7 & 5 & 4 & 7 & $38(40.7)$ \\
\hline Odontoma & 1 & & & 1 & & & $2(2.2)$ \\
\hline Epulis & 1 & 1 & 4 & 6 & 1 & 2 & $15(16.0)$ \\
\hline Hemangioma & 3 & 1 & & 1 & 2 & 2 & $9(9.7)$ \\
\hline Lymphangioma & 2 & & & & & & $2(2.2)$ \\
\hline Myxoma & 2 & 1 & 2 & & 1 & 1 & $7(7.5)$ \\
\hline Osteoma & 1 & & & 1 & 3 & 1 & $6(6.5)$ \\
\hline Endothelioma & 1 & & 2 & 1 & 2 & 2 & $8(8.6)$ \\
\hline Leukoplakia & & & 1 & & & & $1(1.1)$ \\
\hline Lipoma & & & & & & 1 & $1(1.1)$ \\
\hline Sialoma & & & 1 & & & & $1(1.1)$ \\
\hline Papilloma & & & & & 1 & & $1(1.1)$ \\
\hline Others & & 1 & 1 & & & & $2(2.2)$ \\
\hline Total & 15 & 15 & 18 & 15 & 14 & 16 & $93(100.0)$ \\
\hline
\end{tabular}


The 93 cases of benign tumor were divided into 51 cases $(54.3 \%)$ of non-odontogenic tumor; 40 cases $(43.6 \%)$ of odontogenic tumor; and two cases of unknown origin. The distribution of cases among males (42 cases) and females (51 cases) indicates no sex-related incidence.

Of the odontogenic tumors, the most predominant group was ameloblastoma with 38 cases. Epulis comprised 15 of the 51 non-odontogenic tumor cases.

10. Malignant Tumor

Ninety-nine cases of malignant tumors were documented during the six-year period. Of these, 90 cases occurred in patients above forty years of age. There were 5 cases $(5.1 \%)$ within the $30-40$ year group and 3 cases $(3.1 \%)$ within the $20-30$ year group. The youngest case was a two-year old boy with a reticulosarcoma ${ }^{2}$.

a. Sex and Histological Diagnosis (Table 13-a)

Table 13-a. MALIGNANT TUMOR

\begin{tabular}{|c|c|c|c|c|c|c|c|c|}
\hline & \multicolumn{2}{|c|}{$\operatorname{sex}$} & \multicolumn{6}{|c|}{ Microscopic diagnosis } \\
\hline & male & female & $\begin{array}{l}\text { Squamous } \\
\text { Cell Ca. }\end{array}$ & $\begin{array}{l}\text { Ca. } \\
\text { Simplex }\end{array}$ & $\begin{array}{l}\text { Adenoid } \\
\text { Cystic Ca }\end{array}$ & $\begin{array}{l}\text { Basal Cell } \\
\text { Ca. }\end{array}$ & unknown & recurrence \\
\hline \multicolumn{9}{|l|}{ Carcinoma } \\
\hline Maxillary sinus & 18 & 11 & 21 & 4 & 1 & & 3 & 8 \\
\hline Gums & 11 & 5 & 9 & 4 & 2 & 1 & & 3 \\
\hline Tongue & 11 & 5 & 14 & 1 & & & 1 & 4 \\
\hline Buccal mucosa & 5 & 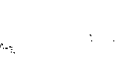 & 4 & 1 & & & & \\
\hline Floor of the mouth & 6 & & 5 & & & & 1 & 2 \\
\hline Nasopharynx & 2 & 1 & 2 & & 1 & & & \\
\hline Lips & 2 & & 2 & & & & & \\
\hline Total & 55 & 22 & $\begin{array}{c}57 \\
(74.0)\end{array}$ & $\begin{array}{c}10 \\
(13.0)\end{array}$ & $\begin{array}{c}4 \\
(5.2)\end{array}$ & $\stackrel{1}{(1.3)}$ & $\begin{array}{c}5 \\
(6.5)\end{array}$ & 17 \\
\hline Sarcoma & 2 & 2 & & & & & & \\
\hline
\end{tabular}

In carcinoma, the ratio of male (55 cases) to female (22 cases) incidence was 2.5 to 1 . There were two cases each of sarcoma in male and female patients. The microscopic diagnosis for 77 patients with carcinoma indicated the following distribution: $74 \%$ with squamous cell carcinoma; $13.0 \%$ carcinoma simplex; $5.2 \%$ adenoid cystic carcinoma; $1.3 \%$ basal cell carcinoma; and $6.5 \%$ unknown.

b. Treatment (Table 13-b)

The treatment for 94 patients with carcinoma consisted of the following:

(1) Surgical resection and chemotherapy $-40.5 \%$

(2) Combined surgical resection, chemotherapy and radiotherapy $-32.9 \%$

(3) Radiotherapy and chemotherapy - 6.4\%

(4) Surgical resection and radiotherapy -- $2.1 \%$

c. TNM and Stage Classification (Table 14)

The site and the degree of the tumor in the clinical feature were categorized 
Table 13-b. MALIGNANT TUMOR (type of the treatment)

\begin{tabular}{|c|c|c|c|c|c|c|c|c|c|c|}
\hline & \multicolumn{2}{|c|}{$\mathrm{S}+\mathrm{C}$} & \multicolumn{2}{|c|}{$\mathrm{S}+\mathrm{C}+\mathrm{R}$} & \multirow{2}{*}{$S+R$} & \multicolumn{2}{|c|}{$\mathrm{R}+\mathrm{C}$} & \multirow{2}{*}{ IAI } & \multirow{2}{*}{ others } & \multirow{2}{*}{$\underset{(\%)}{\text { Total }}$} \\
\hline & $\mathrm{S}+\mathrm{C}$ & $S+I A I$ & $\mathrm{~S}+\mathrm{C}+\mathrm{R}$ & $\begin{array}{r}\mathrm{S}+\mathrm{IAI} \\
+\mathrm{R}\end{array}$ & & $\mathbf{R}+\mathrm{IAI}$ & $R+C$ & & & \\
\hline \multicolumn{11}{|l|}{ Carcinoma } \\
\hline Maxillary sinus & 1 & 12 & 5 & 10 & 1 & 1 & 1 & & 6 & 37 \\
\hline Gums & 1 & 8 & 3 & 4 & & & 1 & 1 & 1 & 19 \\
\hline Tongue & 2 & 6 & 1 & 1 & & 1 & 2 & 2 & 5 & 20 \\
\hline Buccal mucosa & 1 & & 1 & 2 & & & & & 1 & 5 \\
\hline Floor of the mouth & 1 & 3 & 1 & 1 & 1 & & & & 1 & 8 \\
\hline Nasopharynx & 1 & & 2 & & & & & & & 3 \\
\hline Lips & 1 & 1 & & & & & & & & 2 \\
\hline Total & $\begin{array}{l}8 \\
(8.5)\end{array}$ & $\begin{array}{c}30 \\
(32.0) \\
\end{array}$ & $\begin{array}{c}13 \\
(13.8)\end{array}$ & $\begin{array}{c}18 \\
(19.1)\end{array}$ & $\begin{array}{c}2 \\
(2.1)\end{array}$ & $\begin{array}{c}2 \\
(2.1)\end{array}$ & $\begin{array}{c}4 \\
(4.3)\end{array}$ & $\begin{array}{c}3 \\
(3.2) \\
\end{array}$ & $\begin{array}{c}14 \\
(14.9)\end{array}$ & $\begin{array}{r}94 \\
(100.0) \\
\end{array}$ \\
\hline Sarcoma & & & 1 & & & & 1 & & 2 & 4 \\
\hline
\end{tabular}

$S$ : surgical resection

$\mathrm{C}:$ chemotherapy

$\mathrm{R}$ : radiotherapy

IAI : intra-arterial infusion

Table 14. STAGE AND T.N.M. CLASSIFICATION

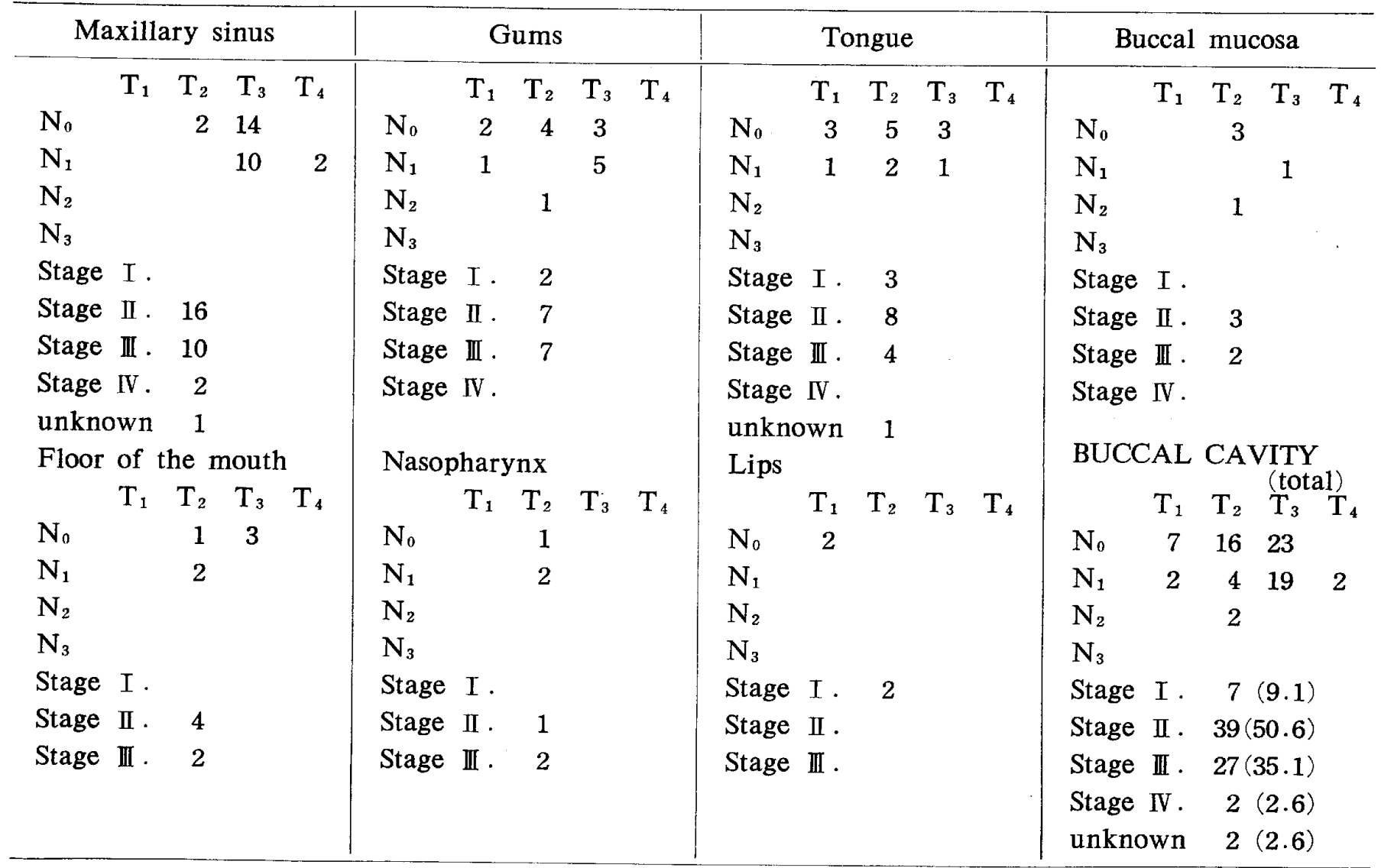

the TNM classification proposed by the UICC (Union Internationale Contre le Cancer ${ }^{3}$ ). The maxillary sinus cases which had not been classified were divided according to the 
Japanese drafts ${ }^{4.5}$.

Primary lesions were located in the following areas: maxillary sinus- -28 cases ( 36 . $3 \%)$; gums -16 cases $(20.8 \%)$; tongue -15 cases $(19.5 \%)$; floor of the mouth -6 cases

$(7.8 \%)$; buccal mucosa-5 cases $(6.5 \%)$; nasopharynx-3 cases $(3.9 \%)$; and lips -2 cases $(2.6 \%)$. The details of TNM classification are as follows: $\mathrm{T}_{1}-9$ cases $(11.7 \%)$; $\mathrm{T}_{2}-22$ cases $(28.6 \%) ; \mathrm{T}_{3}-42$ cases $(54.5 \%) ;$ and $\mathrm{T}_{4}-2$ cases $(2.6 \%)$. They were analyzed according to their location in the buccal cavity. $\mathrm{T}_{3}$ accounted for 24 cases $(85.7 \%)$ of the 28 cases in the maxillar ysinus, and 5 of the 6 cases in the floor of the mouth. Of the cases of carcinoma of the lips, tongue and buccal mucosa, there were 22 cases $(77.3 \%)$ of $\mathrm{T}_{2}$.

By far the majority of cases (46 cases; $59.7 \%$ ) were classified within the $\mathrm{N}_{0}$ group. There were 27 cases $(35.1 \%)$ of $\mathrm{N}_{1}$ and 2 cases $(2.6 \%)$ of $\mathrm{N}_{2}$. Lymphonodi metastasis, which are recognized as a clinical feature, were developed as far as the $N_{1}$ degree in all of the cases involving the maxillary sinus, the tongue, the floor of the mouth and the nasopharynx. There was one case each of $\mathrm{N}_{2}$ on the gums and the buccal mucosa. No metastasis was found.

Stage I had 7 cases $(9.1 \%)$; Stage I had 39 cases $(50.6 \%)$; Stage II had 27 cases $(35.1 \%)$; and Stage $\mathbb{N}$ had just 2 cases $(2.6 \%)$.

d. Survival Rate for Three-year Period (Table 15)

Table 15. SURVIVAL RATE FOR THREE-YEAR PERIOD

\begin{tabular}{l|c|c|c|c|c} 
& case & death & surviv & survival rate (\%) & unknown \\
\hline Maxillary sinus & 20 & 14 & 4 & 20.0 & 2 \\
Gums & 11 & 5 & 5 & 45.5 & 1 \\
Tongue & 10 & 3 & 6 & 60.0 & 1 \\
Buccal mucosa & 3 & 2 & & 0 & 1 \\
Floor of the mouth & 4 & 2 & 2 & 50.0 & \\
Lips & 1 & & 1 & 100.0 & 5 \\
\hline Total or mean & 49 & 26 & 18 & 36.7 & 5 \\
\hline
\end{tabular}

Of the 49 cases of malignancies within the buccal cavity, the absolute survival rate for those passing the three-year point after date of admission was $36.7 \%$. The three-year survival rate for carcinoma in the maxillary sinus was $20.0 \%$, but all other sites had nearly a $50 \%$ or higher survival rate (Table 15) .

The majority of carcinoma occur in the maxillary sinus, and the yearly survival rate for such cases is shown in Fig. I . During

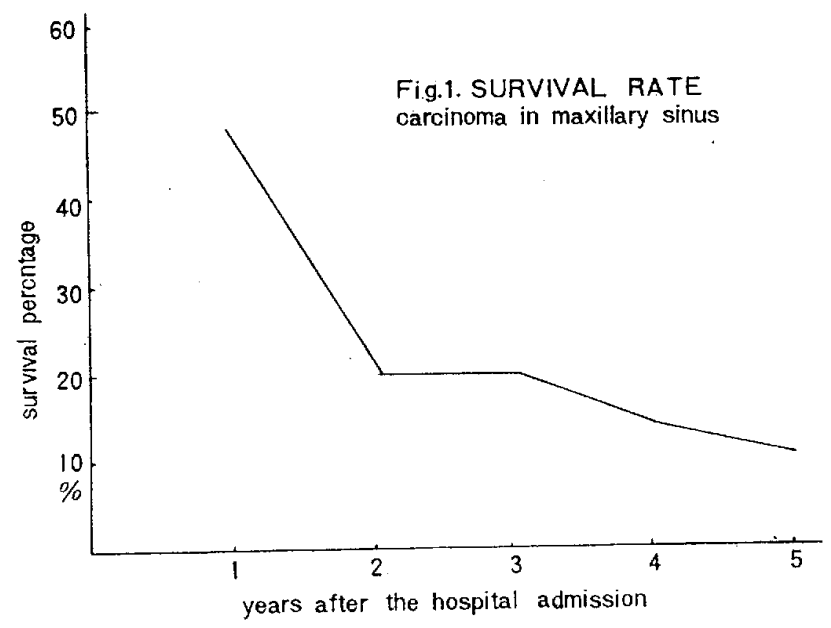


this survey contact was lost with 5 cases $(10.2 \%)$ of the 49 cases and these are regarded as deceased. One of the carcinoma case was that of a central carcinoma in the mandible found in a 46 -year old male who was still alive after three years.

e. Sarcoma

The breakdown of 4 cases of sarcoma resulted in two csaes of reticulosarcoma, one case of lymphosarcoma, and one case of round cell sarcoma. One case survived more than one year and the other cases expired.

Table 16. OTHERS

\begin{tabular}{|c|c|c|c|c|c|c|c|}
\hline & year 1966 & ' 67 & ' 68 & '69 & 70 & 71 & Total $(\%)$ \\
\hline $\begin{array}{l}\text { Trigeminal neuralgia } \\
\text { Glossopharyngealitis } \\
\text { Temporomandibular arthrosis } \\
\text { Temporomandibular ankylosis } \\
\text { Sialolithiasis } \\
\text { Postoperative hemorrage } \\
\text { Hemopathy } \\
\text { Exostosis } \\
\text { Enostosis } \\
\text { Osteosclerosis } \\
\text { Abnormal absorprion of the } \\
\text { alveolar process } \\
\text { Impacted tooth } \\
\text { Tooth defect } \\
\text { Driven into the sinus } \\
\text { Foreign body } \\
\text { Caries } \\
\text { Scar contraction } \\
\text { Pyorrhea } \\
\text { Dilantin gingival hyperplasia } \\
\text { Ulcerative stomatitis } \\
\text { Hyperplasia of the M. masseter } \\
\text { Hyperkeratosis } \\
\text { None oral disease }\end{array}$ & $\begin{array}{l}1 \\
1 \\
1\end{array}$ & $\begin{array}{l}2 \\
1 \\
1 \\
1\end{array}$ & $\begin{array}{l}2 \\
1 \\
1\end{array}$ & $\begin{array}{l}1 \\
2 \\
4 \\
4 \\
1 \\
1\end{array}$ & $\begin{array}{l}2 \\
1 \\
1 \\
1\end{array}$ & $\begin{array}{l}3 \\
1\end{array}$ & $\begin{aligned} 7 & (10.0) \\
2 & (2.9) \\
7 & (10.0) \\
4 & (5.7) \\
12 & (17.1) \\
7 & (10.0) \\
5 & (7.1) \\
1 & (1.4) \\
1 & (1.4) \\
1 & (1.4) \\
1 & (1.4) \\
1 & (1.4) \\
1 & (1.4) \\
3 & (4.3) \\
2 & (2.9) \\
1 & (1.4) \\
3 & (4.3) \\
2 & (2.9) \\
1 & (1.4) \\
2 & (2.9) \\
1 & (1.4) \\
1 & (1.4) \\
4 & (5.7)\end{aligned}$ \\
\hline Total & 7 & 12 & 9 & 19 & 13 & 10 & $70(100.0)$ \\
\hline
\end{tabular}

\section{V) Discussion}

The 2nd Department of Oral Surgery at Kyushu Dental College covered the period beginning in October 1965. During the ensuing six years 1,306 inpatients were analyzed from a statistical point of view. The guiding principle in our daily work was one of a dynamic therapeutic change.

As reported by Sekiyama ${ }^{6}$ in 1966 , the malformation group was the most frequently encountered case.

Malformation $(43.4 \%)$, inflammation $(18.1 \%)$, and cystic disease $(10.0 \%)$ accounted 
for a total of $71.5 \%$ of all cases. This indicates a need to educate patients in oral hygiene and regular treatment, for these maladies are apt to follow caries involvement and endodontic therapy. The mean hospitalization period for each group was 1.5 times longer than that experienced by Matsuo (1971) ${ }^{7}$.

Our bed occupancy rate showed just over $60 \%$ when the figures for malformation $(43.9 \%)$ and malignant tumor $(17.5 \%)$ are combined. Matsuo also reported that these two diseases occupied two-thirds or more of the beds, but the percentages for the two diseases were different: $46.6 \%$ for malignant tumor and $14.5 \%$ for malformation. There is a difference in the number of patients treated in the depatment of oral surgery of the medical faculty and of the dental college. In spite of the differences in figures, these two groups have an important significance for the surgeons in oral surgery.

Malformation

The ratio of cleft lip, cleft lip and palate, and cleft palate was $1: 2: 2$. In the $U$. S.A. it is $1: 2: 1$ (Robert) ${ }^{8}{ }^{8}$; New Zealand $1: 1.6: 1.5$ (Susuki) ${ }^{9}$; Turkey 1:0.6:0.8

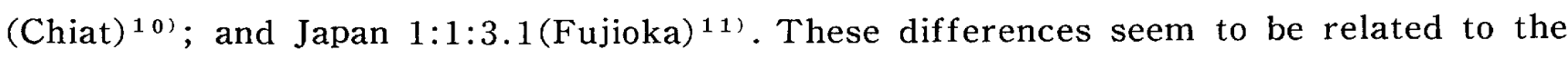
location of each medical center, its environmental factors and statistical dealings. Incidentally, our figures included not only new born infants, but all of the non-operased cases, as well.

The cases of malformation on the left side were predominans $(1.9$ times by Susuki and 4.0 times by Fujioka). Our result also shows that malformation of the left side occurs 1.7 times more frequently than that of the right side. There were within the malformation group 230 cases of secondary repair because the patients had malformation in the past and were considered to be within the same category. They visited our hospital with complaints of aethetical disturbances and speech difficulties. Such cases present a difficult problem of not only operative technic, but also that of speech therapy.

Ten cases of secondary cheiloplasty in 1971 were performed by lip adhesion procedures. The result and prognosis of these still require future investigation.

\section{Inflammation}

Odontogenic inflammation occurred in 195 cases and about half of them (90 cases) were periostitis. These patients had taken little ingestion due to trismus by swelling and pain and their general body status had deteriorated. Along with dental treatment, the patient must be careful about general health from the beginning of his dental treatment program.

Traumatic Disease

Kuno $(1971)^{12)}$ reported that fractures were concentrated in the ten to thirty age group, and Goldberg $(1969)^{13}$ also reported sixty-four percent of the fractures were from age twenty to forty. The ratio of men and women was 5.2:1 (Kuno) and 2.5:1 (Goldberg).

Our figures indicated 77 cases $(70.0 \%)$ in the age group from ten to forty, with a 
male/female ratio of $4: 1$. It seems to reflect the extent of men's social and working activities. Traffic accidents and industrial or labor-connected accidents were predominant in this etiology. The greater part (103 cases, $76.3 \%$ ) of fractures occurred in the mandible. Seventy-seven cases $(70.0 \%)$ were found in the ten to forty age group

(Table 3). There were 102 fracture cases in 138 locations. Double fractures and triple fractures accounted for 28 cases $(27.5 \%)$ and 4 cases $(3.9 \%)$, respectively. Table 10 shows each anatomic area where the fracures occurred. The frequency of occurrences in each area is shown as a single fracture.

The pattern of double fracture in 28 cases shows that five cases $(17.9 \%)$ occurred in the horizontal ramus posterior and the neck of the condyle; four cases $(14.3 \%)$ were in the horizontal ramus anterior and the angle; and three cases $(10.7 \%)$ were in the horizontal ramus anterior and alveolus. The angle and the neck of the condyle had one case each.

The details of the four triple fracture cases showed one patient with the bilateral neck of the condyle and the angle. Another patient had triple fracture in the neck of the condyle and in the anterior and posterior horizontal ramus. A third patient's was at the ascending ramus and in the anterior and posterior horizontal ramus. The fourth patient suffered fractures at the angle, the neck of the condyle and the posterior horizontal ramus. As an etiological factor, traffic accident and labor casualty accounted for $53.0 \%$ and $12.7 \%$, respectively. There were six cases of soft tissue injury only, two cases of dislocation of temporomandibular joint and three cases of dislocation of teeth.

Cystic Disease

Odontogenic and non-odontogenic tumor amounted to sixty-nine and fifty-eight cases, respectively. Of the 69 cases of odontogenic cyst, 53 cases were radicular cyst. It should be noted that the disease occurred after caries and endodontic therapy.

Malignant Tumor

The ratio of men to women was almost $2: 1$ according to other reports. There seems to be a different biological mechanism in the male and female mucous membranes themselves (Matsuo). Carcinoma in maxillary sinus (29 cases), tongue (16 cases), and gums (16 cases) are given in the order of their frequency, and these 61 cases $(78.0 \%)$ made up the greater part of the buccal cavity malignancies. The least frequent was carcinoma in the lips (2 cases, 3.0\%). Matsuo's report listed carcinoma in the tongue (29 cases), maxillary sinus ( 28 cases), and gums (23 cases) in descending order and slightly different from ours. The difference is also evident between medical and dental faculties.

In the $\mathrm{TNM}$ and stage classification, twenty cases $(29.8 \%)$ of $\mathrm{T}_{3} \mathrm{~N}_{0}$ were more prevalent than any other type. Thirty-nine cases of carcinoma in the buccal cavity were listed in Stage II.

The survival rate for carcinoma in maxillary sinus was $20.0 \%$. Other reports of 
survival of maxillary sinus were as follow: Ueno ${ }^{14)}, 11.1 \%$; Yanagino ${ }^{15)}, 23.5 \%$; Ohtani 16) $39.3 \%$; and $\mathrm{Baba}^{17)}, 22.9 \%$. Our survival rates for other sites were $45.5 \%$ for carcinoma of the gums and $60.0 \%$ in the tongue. In carcinoma of the gums, Robert ${ }^{18}$ ) reported $50.6 \%$ and $\mathrm{Ueno}^{19}$ ) reported $27.3 \%$. In the tongue, Robert had $30.0 \%$ and Ueno $^{20} 29.0 \%$. Our survival rates compare favorably with these other figures. Three of eight cases of carcinoma of the buccal mucosa, floor of the mouth, and lips were still alive after three years.

As a treatment of malignant tumors, surgical resection, radiotherapy and chemotherapy are in practice. Surgical excision is the most popular in the present situation. Now chemotherapy (especially for carcinoma) has been developed to such a degree that reports show favorable clinical data, when supplemented with palliative surgical resection. In our department, radiotherapy and chemotherapy are used, limiting the extent of excision to consideration of the post-operative function and the problems of aethetical disturbance.

The cases with intra-arterial infusion via arteria thyroidea superior or temporalis superficialis made up $53.5 \%$ of the cases treated. This is one of the changes in our methods of treatment. The cases after 1967 were treated not by radical neck operation, but by tumorectomy operation with chemotherapy and radiotherapy. Under these conditions, the five-year survival rate will be required for statistical validity.

V) Conclusion

1. The 2nd Department of Oral Surgery, Kyushu Dental College, covered the period beginning in October 1965. The clinical statistics of inpatients during this six-year period were observed and some of the findings were reported in this paper.

2. Since the bed-occupancy rates for malformation and malignant tumor were 43.9 $\%$ and $17.5 \%$, respectively, these two groups were analyzed more thoroughly than other groups.

3. The diseases of the oral cavity and maxillo-facial area, such as malformation, malignant tumor and others were so important in our clinical work that continued research was necessary and our responsibility to our patients in so doing was also recognized.

\section{REFERENCES}

1) Ando, T.: One of Cervical Cyst (case report). Japan J. Oral Surg. 12: 150, 1966.

2) Migita, N.: Reticulosarcoma of Infant in Upper Jaw. Tumor Meeting, Kitakyushu, 1971 .

3) UICC: TNM Classification of Malignant Tumors. Geneva, 1968.

4) Kitamura, T.: TNM Classification - cancer of the maxillary sinus. JAPAN JOURNAL OF CANCER CLINICS 13: 405, 1967.

5) Imai, T.: International Clinical Stage Classification of Cancer - TNM Classification. JAPAN JOURNAL OF CANCER CLINICS 13: 296, 1967.

6) Sekiyama, S., et al.: Clinical Statistic of 654 Inpatients in the Department Den- 
tistry in 1966. J.J.S.S. 17: 578, 1968.

7) Matsuo, S.: Clinical Statistics. part I, J.J.S.S. 20: 474, 1971.

8) Robert, H. B.: Classification and frequency of cleft lip and/or Palate. Cleft palate J. $6: 40,1969$.

9) Susuki, T.: Statistic Review of the Cleft lip and Palate in Middlemore Hostpital, New Zealand. Jap. J. of Plastic \& Reconstructive Surg. 14: 424, 1971.

10) Chiat, B.: An Analysis of 1000 Cases of Cleft Lip and Palate in Turkey. Cleft Palate J., 6: 210, 1969.

11) Fujioka, Y., et al., Clinical Statictic of Inpatient for Five Years in Iwate Medical University School of Dentistry. J.J.S.S. 20: 592, 1971.

12) Kuno, K., et al.: Clinical Observation of Jaw and Alveolar Fracture in the Past Ten Years. Japan. J. of Oral Surg. 17: 502, 1971.

13) Goldberg. G. M., A. C. Williams.: The Location and Occurrence of Mandibular Fracture. Oral Surg., Oral Med., \& Oral Path. 28: 336, 1969.

14) Ueno, T., et al.: Study on the Treatment and Prognosis of Carcinoma of the Mouth, Part II. Japan. J. Oral Surg. 6: 407, 1960.

15) Yanagino, K.: A Clinical Observation on Malignant Tumor of the Maxillary Sinus. Otologia (Tokyo) 36: 15, 1964.

16) Ohtani, L.: Statistical Observation on Maxillary Cancer in Recent Ten Years. Otologia (Tokyo) 42: 145, 1970.

17) Baba, S.: Irradiation Therapy of the Carcinoma of the Paranasal Sinus: A Clinical Study. JAPAN JOURNAL OF CANCER CLINICS 13: 1025, 1967.

18) Robert, T. N.: Experience with Radical Neck Dissection in the Management of 246 Patients with Malignant Tumor of the Head and Neck. Ann. Surg. 167: 23, 1968.

19) Ueno, T., et al.: Study on the Treatment and Prognosis of Carcinoma of the Mouth. Part III. Kokubyo Z. 28: 432, 1961.

20) Ueno, T., et al.: Study on the Treatmentand Prognosis of the Mouth. Part I . Japan. J. Oral Surg. 6, 396, 1960.

21) Ueno, T., et al.: Study on the Treatment of Carcinoma of the Mouth. Part IV. Japan. J. Oral Surg. 9, 65, 1963.

22) Ueno, T., et al.: Study on the Treatment of Carcinoma of the Mouth. Part V. Japan. J. Oral Surg. 9, 92, 1963.

23) Archer, W. H.: Oral Surgery, 4th edition. W.B. Saunders Company, 1966.

24) Shafer, W. G., Hine, M. K. and Levy, B. M.: A Textbook of Oral Pathology, second edition. W. B. Saunders Company, 1964.

25) Nakamura, H., et al.: Oral Surgery. M.D.P. Corp., 1971. 


\title{
過去6年間における入院患者の臨床的統計
}

\author{
九州菌科大学第 2 口腔外科学教室（指導 池尻 茂教授) \\ 北村晃・神原淳・河野 信彦 \\ 永井 龍介・中富 俊介
}

昭和 41 年 1 月より，昭和 46 年 12 月まで，過去 6 年間に わたる, 九州潾科大学第 2 口腔外科学教室入院患者は, 総計 1,306 例, 年平均 217 例となり, 男女それぞれ732例， 574例であった，年䑪別では 9 才以下の若年者例が477例 ともっとも多く，乙の現象は橉科口腔外科衫療体系の一 端を示すものとして興味深い。月別入院症例数では 1 月 に入院がわずかに多く見られた以外特別の差は見られな かった。個々の疾患別汇見た場合，奇形，炎症，䨢胞性 疾患, 恶性腫痬, 良性腫瘍, その他の順となり, これら の各年別入院患者総数に対する割合はほぼ一定してい た。入院日数では, 悪性腫瘍がもっとも長くほぼ 3 力月 の長期にわたった。この原因は覀性腫場に対し, 積極的 に化学療法ことに動脈内持続注入法を採用しできるだ け，外科手術による奏質欠損を少なくするという治療方 針も若干関係していると思われる。ベッド占有率では, 奇型と悪性腫瘍で $60 \%$ 以上を占め，乙れらの疾患の口腔 外科学的臨林意義の重要性を改めて認識した。徒って,
この二つの疾患群を中心に, 他の疾患群についても検討 を加えた。裂奇形患者の新鮮例では, 口蓋裂のみ抢よび 唇顎口㦈裂例数が口辰裂のみのそれよりも約 2 倍であこ た。愿裂, 唇顎口蓋の口唇形成術はほぼ一支以前に行わ れ, 唇顎口蓋裂, 口蓋裂の口蓋形成術は大部分が 2 才以 前に，抢そくとも5才までにそのほとんどが行われてい る.なお，46年度の口唇形成術の10例は Lip Adhesion が施行され，乙の術式に扔ける子後は後日詳述する。昰 性缠瘍例は裂冾形々対照的に40才以上の高略者が多かっ た.しかし10才以下ことに2才の細綱肉腫症例は, 口腔 外科学診断上配虙の朋要な一端を示すと思われる. 男女 比では，男性が女性の 2 倍老示し注目される。悪性腫瘍 の 3 年生存率の平均は， $36.7 \%$ あるが，もっとも症例 数の多かった上頻洞癌の生存率に大きく左右されたもの と思われた，かかる点が今後口腔領域悪性腫瘍に対する 治潦成績向上の重要なる一面である。乙こに他疾患群も 含め, 6 年間の臨床統計の概要老報告する. 